\title{
Estimation of genetic parameters of test day fat and protein yields in Brazilian Holstein cattle using an autoregressive multiple lactation animal model
}

\author{
C.N. Costa ${ }^{1 \#}$, J. Carvalheira ${ }^{2,3}$, J.A. Cobuci ${ }^{4}$, A.F. Freitas ${ }^{1}$ and G. Thompson $^{2}$ \\ ${ }^{1}$ Embrapa Gado de Leite, 36038-330 Juiz de Fora, MG, Brazil \\ ${ }^{2}$ Research Center in Biodiversity and Genetic Resources (CIBIO-ICETA), University of Porto, Rua Padre Armando \\ Quintas-Crasto, 4485-661 Vairão, Portugal \\ ${ }^{3}$ Institute of Biomedical Sciences Abel Salazar (ICBAS), University of Porto, Portugal \\ ${ }^{4}$ Univ. Federal do Rio Grande do Sul, Animal Science, 91540-000, Porto Alegre, RS, Brazil
}

\begin{abstract}
This study was aimed to estimate variance components and genetic parameters for daily fat and protein yields of Brazilian Holstein cattle, using an autoregressive test day multiple lactations (AR) animal model. Data consisted of test day (TD) records produced by Holstein cows under milk recording supervised by the Brazilian Holstein Association, calving from 1993 to 2004. Medium to high heritability estimates (from 0.18 to 0.30 and from 0.30 to 0.43 for fat and protein TD yields, respectively) suggest opportunities for larger genetic gain by selection. Results from this study confirm the potential of using TD yields to replace the lactation model to estimate breeding values of Holstein cows in Brazil. Further studies are needed to compare these results with other modelling approaches e.g., the RR model.
\end{abstract}

Keywords: Dairy cattle, milk components, selection, test-day model, variance components

\#Corresponding author. E-mail: cnc8@cnpgl.embrapa.br, supported by Fapemig

\section{Introduction}

In the scenario of dairy cattle genetic selection, the possibility to improve breeding value estimation is driving the research aimed at replacing the use of cumulative lactation records by test day (TD) measurements. Random regression (RR) models have been widely studied and evaluated for genetic evaluation at national level in many countries. RR models have the advantage of flexibility to account for the environmental and genetic components of the shape of the lactation curve. Currently, 11 countries are using TD records in their genetic evaluation systems for production in dairy cattle. Among them, eight countries use RR models (Interbull, 2008).

The random regression allows to fit sub-models for adjusting the lactation curve, assumes a structure for genetic and environmental variation specific to individual TD yields and variable correlation between TD yields (Schaeffer, 2004). The use of TD records greatly increases the amount of data to be analyzed, thus requiring the selection of a more parsimonious model with respect to the number of parameters to be estimated. The choice of sub-model for fitting additive genetic and permanent environment effects is the focus in finding an optimal RR model (López-Romero \& Carabaño, 2003; Melo et al., 2007; Costa et al., 2008).

An alternative to the RR models is the autoregressive (AR) TD approach which assumes that TD yield is the product of the expression of the same set of genes throughout the productive life of the cow and, therefore, less parameters need to be estimated. When fitting the three first lactations, the AR model will require estimation of only 10 parameters (six variance components and four autocorrelations), permitting the analyses of more records per cow, which may contribute for higher accuracies of prediction (Carvalheira et al., 2002). Results from Costa et al. (2006) indicated the AR animal model as a potential model to evaluate TD milk yield and replace the lactation model for estimation of breeding values of Holstein cattle in Brazil.

So far no previous study has been done with respect to fitting TD models for daily fat and protein yields of Holstein cattle in Brazil. The objectives of this study were to estimate variance components and genetic parameters for daily fat and protein yields, using an AR animal model. 


\section{Material and Methods}

Data comprised TD records of fat and protein yields from the first three lactations of Holstein cows calving from 1993 through 2004. Records were provided by the Brazilian Holstein Cattle Breeders Association. The editing process was performed according to pre-defined criteria for genetic analysis following assumptions of the AR model (Carvalheira et al., 2002). This included deleting records that were considered outliers, days in milk (DIM) less than five or greater then 305 days, only one daily yield per lactation (L) or with age, test date or DIM out of sequence in a L.

Variance component estimations were based on derivative free REML methodology (Smith \& Graser, 1986). The convergence criterion was met when the variance of the simplex was less than $10^{-8}$. The occurrence of local maxima was checked by two consecutive cold starts without significant change in the log-likelihood (up to four decimal places). The AR animal model was as follows:

$$
y_{i j k l m n o}=H_{T} D_{i}+\operatorname{Age}_{j}\left(H_{k}\right)+\operatorname{DIM}_{m}\left(H_{k} L_{l}\right)+a_{n}+\operatorname{LTE}_{n}+\operatorname{STE}_{n l}+e_{i j k m l n o}
$$

where, $\mathbf{y}$ is the TD observation, HTD is the fixed effect of herd-test-date, Age $\mathbf{( H )}$ is the fixed effect of the age at calving nested within herd, DIM(HL) is the fixed effect of DIM nested within herd and lactation, $\mathbf{a}$ is the random effect of the animal, LTE is the random effect of the long-term environmental effects accounting for the autocorrelations generated by the cow across repeated lactations, STE is the random effect of short term environmental effects accounting for the autocorrelations due to cow within each lactation, and $\mathbf{e}$ is the random residual effect that is assumed to be normally distributed. A detailed description of the model expectations and (co)variance structure is in Carvalheira et al. (2002). Records of the final data were produced by 25943 and 9121 cows, sired by 1370 and 818 sires for fat and protein, respectively. For the pedigree files, all available information was used and only $0.03 \%(0.80 \%)$ and $0.04 \%(1.03 \%)$ of the animals had unknown sires (dams) for the fat and protein pedigree files, respectively.

\section{Results and Discussion} lactation.

Table 1 shows the number of records available for each trait including the phenotypic average for each

Table 1 Number and daily means $( \pm S T D)$ of test day fat and protein records before and after the editing process for Brazilian Holstein cattle ${ }^{\mathrm{A}}$

\begin{tabular}{ccc}
\hline Data & Fat & Protein \\
\hline Original & 259963 & 72940 \\
Final data & 255481 & 72602 \\
$1^{\text {st }}$ Lactation & & \\
Number & 163098 & 42920 \\
Mean \pm STD & $0.79 \pm 0.24$ & $0.77 \pm 0.21$ \\
$2^{\text {nd }}$ Lactation & & \\
Number & 69081 & 21931 \\
Mean \pm STD & $0.90 \pm 0.30$ & $0.88 \pm 0.25$ \\
$3^{\text {rd }}$ Lactation & 23302 & 7751 \\
Number & $235 \pm 0.32$ & $0.93 \pm 0.27$ \\
Mean \pm STD & $0.96 \pm$ \\
HTD $^{C}$ & 1174 & 169
\end{tabular}

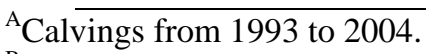

${ }^{\mathrm{B}} \mathrm{kg} /$ day.

${ }^{\mathrm{C}}$ Contemporary Groups of Herd-Test-Date.
} 
Variance components, autocorrelations and genetic parameters for the first three $\mathrm{L}$ of daily fat and protein yields are shown in Table 2. Heritability estimates for the three $\mathrm{L}$ ranged from 0.18 to 0.30 and from 0.30 to 0.43 for fat and protein, respectively. These parameters are larger than those estimated for fat $(0.25)$ and protein (0.22) in Holstein cows' first lactation records adjusted to 305 days (Costa et al., 2007).

The magnitude of variance component estimates for the STE effects compared to the LTE effects (Table 2) indicates that the non-genetic variation due to the repeated effect of cow among TD within a L, accounted for most of the permanent environmental variation. The TD records were consistently highly correlated within each L, ranging from 0.63 in L3 for fat to 0.74 in L1 for protein daily yield.

A small LTE variance associated with a low autocorrelation (Table 2) was also observed for TD milk in Brazilian Holsteins (Costa et al., 2006). As remarked by these authors, this pattern may be expected from breeds with relatively high genetic potential, grown in relatively favourable environments where the impact of events during juvenile growth and dry periods do not have a marked effect on the expression of the trait across L. On the other hand, the STE component measures variation between TD within each L and, therefore, accounting for events occurring during the cow's most sensitive period of her productive lifetime (e.g. udder injury, infection, etc.).

Medium to high heritability estimates (Table 2) indicate opportunities for genetic gains by selection. Figure 1 depicts the mean breeding value by year of birth for fat and protein yields calculated for the dam's path (cows with records).

All means were deviated from the breeding value average of the cows born in 1995. These curves show trends in realized genetic progress for the period between 1990 and 2001. For this study, linear regression coefficients from 1995 to 2001 gave an average annual increase of $0.35 \mathrm{~kg}$ and $1.32 \mathrm{~kg}$ for fat and protein, respectively. These estimates are larger than $0.26 \mathrm{~kg} / \mathrm{year}$ (fat, cows born between 1991 and 2000) and $0.29 \mathrm{~kg} /$ year (protein, cows born between 1989 and 2000) estimated by a lactation model for first lactation Holstein cows (Costa et al., 2005). (Trends including second and third lactation data will show higher annual increases compared to trends based on only $1^{\text {st }}$ lactations as cows usually produce more milk in later lactations compared to first lactation. Selection on breeding values based on inclusion of second and third lactations as well, will have a better improvement in lifetime production than breeding values based only on first lactations).

Table 2 (Co) variance components, autocorrelations and genetic parameters for daily fat and protein yields for Brazilian Holstein cattle

\begin{tabular}{|c|c|c|}
\hline Component & Fat & Protein \\
\hline Genetic variance $^{\mathrm{A}}$ & 0.014 & 0.017 \\
\hline Error variance & 0.012 & 0.006 \\
\hline LTE $^{\mathrm{B}}$ variance & $<0.001$ & $<0.001$ \\
\hline LTE autocorrelation & $<0.001$ & $<0.001$ \\
\hline $\operatorname{STE}^{\mathrm{C}}$ variance $(\mathrm{L} 1)^{\mathrm{D}}$ & 0.021 & 0.016 \\
\hline STE autocorrelation (L1) & 0.695 & 0.741 \\
\hline STE variance $(\mathrm{L} 2)^{\mathrm{D}}$ & 0.040 & 0.028 \\
\hline STE autocorrelation (L2) & 0.654 & 0.719 \\
\hline STE variance $(\mathrm{L} 3)^{\mathrm{D}}$ & 0.051 & 0.034 \\
\hline STE autocorrelation (L3) & 0.631 & 0.669 \\
\hline Phenotypic variance (L1) & 0.046 & 0.039 \\
\hline Phenotypic variance (L2) & 0.066 & 0.052 \\
\hline Phenotypic variance (L3) & 0.076 & 0.057 \\
\hline Heritability (L1) & 0.296 & 0.428 \\
\hline Heritability (L2) & 0.209 & 0.326 \\
\hline Heritability (L3) & 0.180 & 0.295 \\
\hline
\end{tabular}




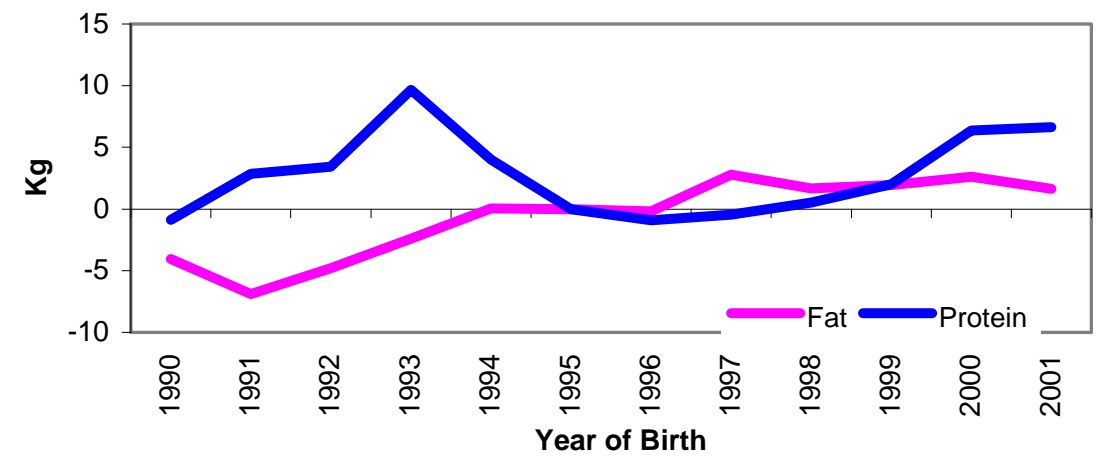

Figure 1 Annual genetic progress for fat and protein of Holsteins cows in Brazil born between 1990 and 2001 (base year $=1995$ ).

\section{Conclusion}

Residual variance, heritability and genetic progress estimates suggest the AR animal model as a potential model to fit TD fat and protein yields of Brazilian Holstein cows and opportunities for larger genetic gain by selection. Results from this study confirm the potential of using TD yields to replace the lactation model to estimate breeding values of Holstein cows in Brazil.

\section{References}

Carvalheira, J., Pollak, E.J., Quaas, R.L. \& Blake, R.W., 2002. An autoregressive repeatability animal model for test-day records in multiple lactations. J. Dairy Sci. 85, 2040-2045.

Costa, C.N., Teixeira, N.M.; Freitas, A.F. \& Cobuci, J.A., 2005. Genetic gains in milk, fat and protein yields of the Holstein breed in Brazil. ADAS, ASAS, CSAS Joint annual meeting. Proc. Cincinatti, Ohio. J. Dairy. Sci. 88, Suppl. 1, 379.

Costa, C.N., Vasconcelos, J., Cobucci, J.A., Thompsom, G. \& Carvalheira, J., 2006. Genetic Parameters of test day milk yields for Brazilian Holstein cattle using an auto regressive multiple lactation animal model. In: World Congress on Genetics Applied to Livestock Production. 8. Belo Horizonte. VIII WCGALP, 2006. [CD-ROM].

Costa, C.N., Freitas, A.F., Cobucci, J.A., Valloto, A.A., Ribas Neto, P.G., Horst, J.A., Barra, R.B., Campos, L.S. \& Marques, A., 2007. Sumário Nacional de Touros da Raça Holandesa. Juiz de Fora: Embrapa Gado de Leite. 66 p. (Documentos, 121). (In Portuguese).

Costa, C.N., Melo, C.M.R., Packer, I.U., Freitas, A.F., Teixeira, N.M. \& Cobuci, J.A., 2008. Genetic parameters for test day milk yield of first lactation Holstein cows estimated by random regression using Legendre polynomials. Rev. Bras. Zootec. 37, 602-608.

Interbull, 2008. <http://www-interbull.slu.se/eval/framesida-prod.htm>. Accessed on June 2008.

López-Romero, P. \& Carabaño, M.J., 2003. Comparing alternative random regression models to analyse first lactation daily milk yield data in Holstein Friesian cattle. Livest. Prod. Sci. 82, 81-96.

Melo, C.M.R., Packer, I.U., Costa, C.N. \& Machado, P.F., 2007. Genetic parameters for test day milk yields of first lactation Holstein cows by random regression models. Animal 1, 325-334.

Schaeffer, L.R., 2004. Application of random regression models in animal breeding. Livest. Prod. Sci. 86, 35-45.

Smith, S.P. \& Graser, H.U., 1986. Estimating variance components in a class of mixed models by restricted maximum likelihood. J. Dairy Sci. 69, 1156-1165. 